\title{
CORRELATION BETWEEN GLUTATHIONE PEROXIDASE ACTIVITY AND THE QUANTITY OF SELENIUM IN THE WHOLE BLOOD OF BEEF CALVES
}

\author{
I. HARAPIN, M. BAUER, L. BEDRICA, D. POTOČNJAK \\ Clinic for Internal Diseases of Domestic Animals, Veterinary Faculty Zagreb, Croatia
}

\author{
Received February 23, 1999
}

Accepted May 31, 2000

Abstract

Harapin I., M. Bauer, L. Bedrica, D. Potočnjak: Correlation Between Glutathione Peroxidase Activity and The Quantity of Selenium in The Whole Blood of Beef Calves. Acta Vet. Brno 2000, 69: 87-92.

The aim of the study was to establish concentration of selenium and the pertinent activity of glutathione peroxidase (GSH-Px ) in whole blood that could be used as reference values in future research. The first part of study was carried out on clinical healthy beef calves $(n=35)$, fed a basal diet and a ready-made fodder mix that contained $0.1 \mathrm{mg} \cdot \mathrm{kg}^{-1}$ selenium. In the second part of our research, we investigated the GSH-Px activity in a group of calves $(n=47)$ that had not received supplements added to the basal diet. The research was carried out in the north-west Croatia, in the region known to be poorer in selenium. We determined GSH-Px activity in whole blood by the "Ransel" method adapted to a Technicon RA-1000 at $37^{\circ} \mathrm{C}$. Determination of Se concentration was done with a modification of the method given by Perkin-Elmer HGGS. The mean value of the Se concentration in the whole blood of the first group of calves was $200.22 \pm 45.2 \mu \mathrm{g} \cdot \mathrm{l}^{-1}$ and pertinent average GSH-Px activity was $764.6 \pm 197.8 \mu \mathrm{kat} \cdot \mathrm{l}^{-1}$. From the results obtained, a correlation between Se and GSH-Px was calculated $(\mathrm{r}=0.82 ; P<0.001)$. The mean values of the GSH-Px activity in herd that did not receive a supplement were $435.3 \pm 155.76 \mu \mathrm{kat} \cdot \mathrm{l}^{-1}$. Out of 47 animals of the second herd, four animals $(8.51 \%)$ had lower values than those recommended as sufficient. This study confirmed that after the calculation of the correlation between Se and GSHPx, glutathione peroxidase activity determination can be used as a rapid and simple proxy for the determination of selenium concentration in whole blood.

Glutathione-peroxidase, selenium, white muscle disease, beef cattle

The discovery that glutathione peroxidase (GSH-Px) protects haemoglobin from oxidative denaturalisation by hydrogen peroxide (Mills 1957) and that the erythrocytes of rats with selenium deficiency are subject to haemolysis brought about by hydrogen peroxide (Rotruck et al. 1972) led to the realisation that glutathione peroxidase is an enzyme which contains the micro-element selenium (Rotruck et al. 1973; Flohe et al. 1973). This knowledge enabled the construction of a biochemical model through which it is possible to monitor the relation between selenium, vitamin E, glutathione peroxidase, polyunsaturated fatty acids and sulphur containing amino acids (Chow and Tappel 1974; Hoekstra 1974). Vitamin E and glutathione peroxidase protect biological membranes from the harmful effect of free radicals. Glutathione peroxidase works in the cytosol of the cell, and vitamin $\mathrm{E}$ is incorporated into the lipid membranes (Smith et al. 1988). Soon after the discovery that glutathione peroxidase is a potent antioxidant, containing four selenium atoms in its molecule, it was determined that there is also a glutathione peroxidase that does not contain selenium (Lawrence and Burk 1978). Scholz et al. (1981) studied the distribution of Se-glutathione peroxidase and non-Se-glutathione peroxidase in calf tissues and blood. It was established that the spleen, cardiac muscle, erythrocytes, brain, thymus, fatty tissue and striated muscles contain only Se-glutathione peroxidase. The liver, lungs, adrenaline, testes and kidneys

Address for correspondence:

Dr. Sc. Ivica Harapin

Clinic for Internal Diseases of Domestic Animals

Heinzelova 55, 10000 Zagreb, Croatia
Phone: +38512390342

Fax: +3851214697

http://www.vfu.cz/acta-vet/actavet.htm 
contain both isozymes. Of the internal organs, the liver had the most non-selenium glutathione peroxidase activity. This statement was confirmed by Pehrson (1985). Scholz and Hutchinson (1979) investigated the distribution of glutathione peroxidase activity and selenium concentration in the body fluids of dairy cows and determined that $98.6 \%$ of glutathione peroxidase activity, when the activity of the enzyme is expressed in $\mathrm{mU} \cdot \mathrm{ml}^{-1}$ of whole blood, is related to erythrocytes in the peripheral blood. In the cellular elements of the blood, there is also a larger proportion of selenium $(73 \%)$ than in the plasma. The research of Thomps on et al. (1981) shows that GSH-Px activity in the plasma is a more sensitive indicator than whole blood activity, but since the values in the plasma are very low, and the results are accordingly less reliable.

Diagnostics are based on detailed data concerning the composition of the soil and feedstuffs, and on laboratory tests that can show selenium deficiency (the element being an indispensable component of the enzyme glutathione peroxidase) and/or vitamin E, as well as on pathohistological evidence of muscles that show muscular degeneration. However, post-mortem findings only confirm the damage, and do not reduce it. Determination of the quantity of selenium in food or in the serum of animals at threat is relatively expensive because it requires a complex equipment. At present, the enzyme glutathione peroxidase has been used as an indicator of the extent to which the organism is supplied with selenium, for glutathione peroxidase has four Se atoms and a very high and significant positive correlation with quantities of selenium in the blood. Although glutathione peroxidase research goes back thirty years, the actual process has only recently been standardised for biochemical analyses. Because of the diversity of methods and ways of presenting the results (authors have not shown the enzyme activities obtained only in terms of IU. $\cdot 1^{-1}$ of whole blood (or in $\mu \mathrm{kat} \cdot \mathrm{l}^{-1}$ ), but linked to haemoglobin content $\left(\mathrm{IU} \cdot \mathrm{gHb}^{-1}\right)$ or packed cell volume value $\left(\mathrm{IU} \cdot \mathrm{ml} \mathrm{PCV}{ }^{-1}\right)$, many data in the literature have not been comparable.

Lack of standardisation in the determination and presentation of the results of glutathione peroxidase activity led us to study this problem. Our research (Harapin 1996) aimed at establishing our own values for glutathione peroxidase activity and the pertinent concentration of selenium in whole blood, which would be usable as reference values in future research.

\section{Materials and Methods}

The experiment was carried out on 35 crossbreed six-month-old Simmental calves. The animals were clinically healthy, and according to anamnesis had not had any kind of sickness for at least one month before the blood samples were taken. They had been fed maize grits silage, whole maize plant silage, hay and a ready-made fodder mix that contained $0.1 \mathrm{mg} \cdot \mathrm{kg}^{-1}$ selenium.

In the second part of the study, we investigated the GSH-Px activity in a group of beef calves that had not received supplements added to the basal diet. The animals were chosen from individual breeds after clinical test. The main criterion was weaker growth and stunted animals. A total of 47 fattened calves, 5-9-month-old were included in the study. The calves had been fed with the usual fattening feed - ground maize corn mixed with cereal crops, maize silage and hay ad libitum. The study was carried out in the north-western Croatia, in the region known to be poorer in selenium, as indicated by previous investigations (Vulinec et al. 1985).

The blood was taken from v. jugularis by the Vacutainer system into test tubes with $143 \mathrm{IU}$ sodium heparinate/7 ml. We determined GSH-Px activity in whole blood by the commercial "Ransel" method from Randox Laboratories Ltd. adapted to a Technicon RA-1000 biochemical analyser at $37^{\circ} \mathrm{C}$. The method was based on the work of Paglia and Valentine (1967), which described a direct spectrophotometric method for determining the glutathione peroxidase of blood cells.

Determination of selenium concentration was done with a modification of the method by Perkin-Elmer HGGS. For a reading of the selenium in the samples, an atomic absorption spectrophotometer had a non-electrode lamp for selenium connected to it as well as apparatus for selenium hydride generation.

The experimental data were statistically evaluated by standard descriptive methods and regression analysis (Chase and Bown 1997) made by SAS Software Release 6.12. 


\section{Results}

Table 1 shows the statistically treated values of glutathione peroxidase shown in $\mu \mathrm{kat} \cdot \mathrm{l}^{-1}$ and $\mathrm{IU} \cdot \mathrm{l}^{-1}$, and selenium in $\mathrm{mg} \cdot \mathrm{l}^{-1}$ of whole blood in the group of calves receiving a supplement with Selenium and vitamin E.

Table 1

Comparative review of glutathione peroxidase activity and selenium concentrations in the group of calves receiving a supplement with Selenium and vitamin $\mathrm{E}(\mathrm{n}=35)$

\begin{tabular}{|l|c|c|c|}
\hline & $\begin{array}{c}\text { GSH-Px } \\
\mu \mathrm{kat} \cdot \mathrm{l}^{-1}\end{array}$ & $\begin{array}{c}\text { GSH-Px } \\
\mathrm{IU} \cdot \mathrm{l}^{-1}\end{array}$ & $\begin{array}{c}\text { Selenium } \\
\mu \mathrm{g} \cdot \mathrm{l}^{-1}\end{array}$ \\
\hline $\mathrm{X}$ & 764.6 & 45780 & 200.22 \\
\hline $\mathrm{SE}$ & 33.4 & 2001.36 & 7.64 \\
\hline SD & 197.8 & 11840.2 & 45.22 \\
\hline Min & 344 & 20.623 & 108.15 \\
\hline Max & 1072 & 64.165 & 283.5 \\
\hline Median & 840 & 50.307 & 206.85 \\
\hline Mod & 116 & 55.965 & 175.35 \\
\hline Skewness & -0.47 & -0.47 & 0.036 \\
\hline Kurtosis & -1.12 & -0.93 & -0.78 \\
\hline
\end{tabular}

From the results obtained, by a linear regression analysis we calculated the regression equation $(\mathrm{Y}=56.6+3.1367 \mathrm{E}-3 * \mathrm{X})$ and determined a correlation between selenium and glutathione peroxidase that is positive and very high $(\mathrm{r}=0.82 ; P<0.001)$.

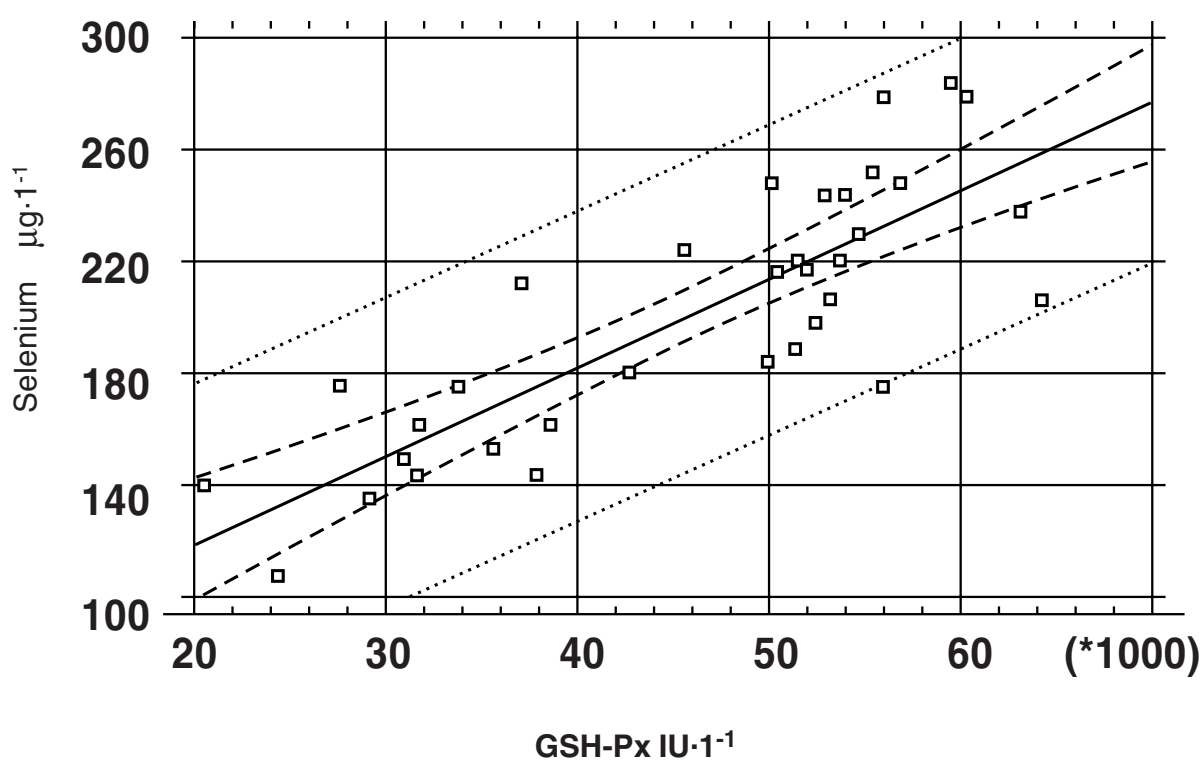

Fig. 1 The regression $(Y=56.6+3.1367 \mathrm{E}-3 * \mathrm{X})$ between selenium and GSH-Px in the whole blood of fattened calves 
Table 2

The GSH-Px activity and selenium quantity in the group of calves that were not receiving selenium and vitamin $E$ as a supplement $(n=47)$

\begin{tabular}{|l|c|c|c|}
\hline & $\begin{array}{c}\text { GSH-Px } \\
\mu \mathrm{kat} \cdot \mathrm{l}^{-1}\end{array}$ & $\begin{array}{c}\text { GSH-Px } \\
\mathrm{IU} \cdot \mathrm{l}^{-1}\end{array}$ & $\begin{array}{c}\text { Selenium } \\
\mu \mathrm{g} \cdot \mathrm{l}^{-1}\end{array}$ \\
\hline $\mathrm{X}$ & 435.32 & 26119.1 & 138.16 \\
\hline SE & 22.72 & 1363.19 & 4.25 \\
\hline SD & 155.76 & 9345.58 & 29.31 \\
\hline Min & 135.0 & 8100 & 82.8 \\
\hline Max & 810.3 & 48600 & 209.1 \\
\hline Median & 417 & 25020 & 135 \\
\hline Mode & 267 & 16020 & 130 \\
\hline
\end{tabular}

Table 2 shows the GSH-Px activity in the whole blood of fattened calves that were not receiving vitamin and mineral supplement in the food. The activity is expressed in $\mu \mathrm{kat} \cdot \mathrm{l}^{-1}$ and IU. $\mathrm{l}^{-1}$, and selenium quantity was calculated by means of a proper regression equation from the first part of the research.

As can be seen from Table 1 and Table 2 the difference in the GSH-Px activity between the two groups of calves is great and statistically significant $(P<0.05)$. The calves that did not receive a supplement in their feed had the activity in whole blood 56.94\% lower than the group which was receiving the supplement. Four calves $(8.51 \%)$ out of 47 had the GSH-Px activity lower than $231 \mu \mathrm{kat} \cdot \mathrm{l}^{-1}$ which according to the proper regression equation corresponds to the selenium quantity lower than $100 \mu \mathrm{g} . \mathrm{l}^{-1}$. In two calves with lowest GSHPx activity (135.04 $\mu \mathrm{kat} \cdot \mathrm{l}^{-1}$ and $148.56 \mu \mathrm{kat} \cdot \mathrm{l}^{-1} \mathrm{GSH}-\mathrm{Px} ; 82.01 \mu \mathrm{g} \cdot \mathrm{l}^{-1}$ and $84.45 \mu \mathrm{g} \cdot \mathrm{l}^{-1}$ of selenium, respectively) the clinical symptoms were not very marked. In spite of this, the animals were sacrificed and at the slaughterhouse the materials for a histopathological examination were sampled. There was found extensive hyaline and vacuolar degeneration in the m. latissimus dorsi, m. triceps and intercostal muscles.

\section{Discussion}

Since glutathione peroxidase activity in erythrocytes is very stable (Wils on and Ju d s on 1976), it can with a great deal of confidence be used in diagnostic purposes, the more so that the antioxidative action of selenium is manifested through glutathione peroxidase activity. Wolf (1998) determined that after selenium supplementation in the diet, GSH-Px followed the positive trend of selenium in the blood up to certain values, after which it reached a plateau and could no longer be used for an estimation of an excess of selenium.

Many authors have described a very high and positive correlation between GSH-Px and selenium, although a regression equation has not been published in most of the works. Lawrence and Burk (1976) established a very high correlation, $r=0.96$; Scholz and Hutchinson (1979) $r=0.958$; Arthur et al. (1979) $r=0.97$; Thompson et al. (1981) $\mathrm{r}=0.97$; Koller et al. (1984) $\mathrm{r}=0.87$; Counotte and Hartmans (1989) $\mathrm{r}=0.93$; Hoshino et al. (1989) $r=0.81$; Heikens (1992) $r=0.77$ and Maas et al. (1993) $r=0.97$. However, Genin and Wolter (1981) found a weak positive correlation $r=0.359$, and Niekerk (1990), too, found a weak correlation that was not strong enough for calculation the selenium concentration.

As can be seen from the results shown, most authors have established a strong positive correlation between quantity of selenium and GSH-Px activity, while the glutathione peroxidase activity stated has been very uneven. This is contributed to by the use of various different units in which to state the results, and still more by various determination methods, 
different reaction temperatures in vitro and the use of diverse anticoagulants. Almost all authors put the lower limiting value for the quantity of selenium in whole blood somewhere between 50 and $100 \mu \mathrm{g} \cdot \mathrm{l}^{-1}$, while nothing like the same degree of unanimity of results has been attained for GSH-Px activity. For this reason each laboratory should make its own regression equation.

Arthur et al. (1979) determined for a selenium concentration of $96 \mu \mathrm{g} \cdot \mathrm{l}^{-1}$ a corresponding glutathione peroxidase activity of $14360 \mathrm{IU} \cdot \mathrm{l}^{-1}$, and used $50 \mu \mathrm{g} \cdot \mathrm{l}^{-1}$ of Se and $5000 \mathrm{IU} \cdot \mathrm{l}^{-1}$ GSH-Px as limiting values. Th o m p s on et al. (1981) obtained a value of $8000 \mathrm{IU} \cdot \mathrm{l}^{-1}$ for 100 $\mu \mathrm{g} \cdot \mathrm{l}^{-1}$, and took this value as sufficient for antioxidative activity. Pehrs on et al. (1985) give $25 \mu \mathrm{g} \cdot \mathrm{l}^{-1} \mathrm{Se}$ and $100 \mu \mathrm{kat} \cdot \mathrm{l}^{-1}$ of GSH-Px as the limiting values below which there is a threat of deficiency accompanied by clinical symptoms. Moreas (1986), from Cestnik et al. (1991) determined the values between $200-250 \mu \mathrm{kat} \cdot \mathrm{l}^{-1}$ as limiting values of the GSH-Px activities, pointing at the satisfactory supply of animals with selenium. Tasker et al. (1987) present $75.9 \mu \mathrm{g} \cdot \mathrm{l}^{-1}$ of selenium, and an activity of $18100 \mathrm{IU} \cdot \mathrm{l}^{-1}$ as values obtained after dietary supplementation for cattle in a farm in an area low in selenium. According to the data by Cestnik et al. (1989) the cattle under study had the $201.4 \mu \mathrm{kat} \cdot \mathrm{l}^{-1} \mathrm{GSH}-\mathrm{Px}$ activity in the whole blood, and the investigated calves from birth to 65 days of age had the GSH-Px activity which was decreasing from $229.1 \mu \mathrm{kat} \cdot \mathrm{l}^{-1}$ to $164.5 \mu \mathrm{kat} \cdot \mathrm{l}^{-1}$ on an average. Hog an et al. (1990) presented a blood selenium value for milk cows of $270 \mu \mathrm{g} \cdot \mathrm{l}^{-1}$ and a corresponding glutathione peroxidase activity value of $80 \mathrm{IU} \cdot \mathrm{l}^{-1}$, while Ellis on (1992) presents $19.75 \mu \mathrm{g} \cdot \mathrm{l}^{-1}$ of selenium and a glutathione peroxidase activity of $2000 \mathrm{IU} \cdot \mathrm{l}^{-1}$ as the lower limiting values in New Zealand.

The mean values of the GSH-Px activity in our herd that did not receive a supplement with vitamin E and selenium, were $435.3 \mu \mathrm{kat} \cdot \mathrm{l}^{-1}\left(138.164 \mu \mathrm{g} \cdot \mathrm{l}^{-1} \mathrm{Se}\right)$. Out of 47 animals, four animals $(8.51 \%)$ had lower values than those recommended as sufficient, and in two animals a lack of selenium is confirmed by histopathological examination of the muscle tissue.

This study has confirmed that after the calculation of the correlation between selenium and GSH-Px $(\mathrm{r}=0.82 ; P<0.001$; regression equation $\mathrm{Y}=56.6+3.1367 \mathrm{E}-3 * \mathrm{X})$, glutathione peroxidase activity determination can be used as a rapid and simple proxy for the determination of selenium concentration in whole blood. In our investigation for a limiting value of $100 \mu \mathrm{g} \cdot \mathrm{l}^{-1}$ selenium in the whole blood, the pertinent activity of $231 \mu \mathrm{kat} \cdot \mathrm{l}^{-1}(13850$ $\left.\mathrm{IU} \cdot \mathrm{l}^{-1}\right) \mathrm{GSH}-\mathrm{Px}$ can be used as a limiting value for selenium deficiency.

\section{Korelace mezi aktivitou glutathion peroxidázy a množstvím selénu v krví masných telat}

Aktivita glutathion peroxidázy byla sledována $\mathrm{v}$ celé krvi telat - kř́ženců plemene Simmental, která byla krmena krmnou dávkou obohacenou směsí vitamínů a minerálních látek s přídavkem $0.1 \mathrm{mg} \cdot \mathrm{kg}^{-1}$ selénu. Mezi aktivitou enzymu a obsahem selénu byla vysoká pozitivní korelace $(\mathrm{r}=0.82 ; P<0.001)$. Výsledky pokusu ukázaly, že aktivita $231 \mu \mathrm{kat} \cdot \mathrm{l}^{-1}$ $\left(13850 \mathrm{IU} \cdot \mathrm{l}^{-1}\right) \mathrm{v}$ celé krvi telat odpovídala koncentraci selénu $100 \mu \mathrm{g}^{-1} \mathrm{v}$ celé krvi. Regresní rovnici $(\mathrm{Y}=56.6+3.1367 \mathrm{E} .3 * \mathrm{X})$ lze použít k výpočtům obsahu selénu v krvi.

\section{References}

ARTHUR, J. R, PRICE, J., MILLS, C. F. 1979: Observations on the selenium status of cattle in the north-east of Scotland. Vet. Rec. 104: 340-341

CHASE, W., BOWN, F. 1997: General Statistics, 3rd ed. John Wiley and Sons Inc. New York, USA

CHOW, C. K., L. TAPPEL, A. L 1974: Response of glutathione peroxidase to dietary selenium in rats. J. Nutr. 104: 444 -451 CESTNIK, V., PARDUBSKY, T., ČEBULJ NINA, KOBAL SILVESTRA, GLOBOČNIK, T. 1989: Blood glutathione peroxidase activity in domestic animals. Zb. Biotehn. fak. Univ. E. Kardelja, Vet. 26:73-81

COUNOTTE, G. H. M., HARTMANS, J., 1989: Relation between selenium content and glutathione-peroxidase activity in blood of cattle. Vet. Quart. $11: 155-160$ 
ELLISON, R. S., 1992: A review of copper and selenium reference ranges in cattle and sheep. Vet. Cont. Edu. 145, 3-27, Massey University.

FLOHE, L., GUNZLER, W. A., SCHOCK, H. H. 1973: Glutathione Peroxidase: a selenoenzime. FEBS Lett., 32 : 132.

GENIN, F., WOLTER, R. 1981: Experimental diagnosis of selenium deficiency. Practical method of determining blood glutathione peroxidase in the cow. Revue de Med. Vet. 132:173-180; 183-188

HARAPIN, I. 1996: The role of glutathione peroxidase in myopathy and myocardiopathy in fattened calves (Značenje glutation peroksidaze u miopatija i miokardiopatija junadi u tovu). PhD. Thesis, Veterinary faculty, Zagreb. $151 \mathrm{p}$.

HEIKENS, A. 1992: Studies on the selenium content of home-produced feeds and on selenium supply of horses and ruminants in East Friesland (Germany). Thesis, Tierärztliche Hochschule Hannover, Germany. 160 p.

HOEKSTRA, W. G. 1974: Biochemical role of selenium. From: Hoekstra W. G., J. W. Suttie, H. E. Ganther, W. Mertz, Trace Element Metabolism in Animals. 2 ed. Baltimore University Park, Baltimore.

HOGAN, J. S. SMITH, K. L. WEISS, W. P. TODHUNTER, D. A., SCHOCKEY, W. L. 1990: Relationships among vitamin E, selenium, and bovine blood neutrophils. J. Dairy Sci. 73: 2372-2378

HOSHINO, Y., ICHIJO, S., OSAME, S., TAKAHASHI, E. 1989: Studies on serum tocopherol, selenium levels and blood glutathione peroxidase activities in calves with white muscle disease. Jap. J. Vet. Sci. 51: 741-748

KOLLER, L. D., SOUTH, P. J., EXON, J. H., WHITBECK, G. A., MAAS, J. 1984: Comparison of selenium levels and glutathione peroxidase activity in bovine whole blood. Can. J. Comp. Med. 48: 431-433

LAWRENCE, R. A., BURK, R. F. 1976: Glutathione peroxidase activity in selenium deficient rat liver. Biochem. Biophys. Res. Commun. 71: 952-958

LAWRENCE, R. A., BURK, R. F. 1978: Species, tissue and subcellular distributtion of non Se dependent glutathione peroxidase activity. J. Nutr. 108: 211- 215

MAAS, J., PEAUROI, J. R., TONJES, T., KARLONAS, J., GALEY, F. D., HAN B. 1993: Intramuscular selenium administration in selenium-deficient cattle. J. Vet. Int. Med. 7: 342-348

MILLS, G. C. 1957: Hemoglobin catabolism I. Glutathione peroxidase, an erythrocyte enzyme which protects hemoglobin from oxidative breakdown. J. Biol. Chem. 229: $189-197$

MOREAS, S. 1986: Untersuchungen zu Abhängigkeit der Zink-, Mangan- und Selengehalte in Lebern von Rinden aus ausgewählten Regionen Brasiliens. Inaugural Disertation, Tierärztliche Hochschule, Hannover, German Federal Republic. (From CESTNIK, V., ČEBULJ-KADUNC NINA, PARDUBSKY T. 1991: Whole blood glutathione peroxidase activity (GSH-Px) in cattle and sheep in some regions in Slovenia. Zb. Vet. fak. Univ. Ljubljana 28, 125-131.).

NIEKERK, F. E. van, CLOETE, S. W. P., BARNARD, S. A., HEINE, E. W. P. 1990: Plasma copper, zinc and blood selenium concentrations of sheep, goats and cattle. South African J. Anim. Sci. 20: 144-147

PAGLIA, D. E., VALENTINE W. N. 1967: Studies on the quantitative and qualitative characterisation of erythrocyte glutathione peroxidase. J. Lab. Clin. Med. 70: 158-169

PEHRSON, B. 1985: Selenium dependent and non selenium dependent glutathione peroxidase activity in tissues from young bulls. Zbl. Vet. Med. A, 32: 488-491

ROTRUCK, J. T., POPE, A. L., GANTHER, H. E., HOEKSTRA, W. G. 1972: Prevention of oxidative damage to rat erytrocytes by dietary selenium. J. Nutr. 102:689- 696

ROTRUCK, J. T., POPE, A. L., GANTHER, H. E., SWANSON, A. B., HAFEMAN, D. G., HOEKSTRA, W. G. 1973: Selenium: biochemical role as a component of glutathione peroxidase. Science 179: 588 -590

SAS Software Release 6.12. Copyright @ $1989-1996$ by SAS Institute Inc., Cary, NC, USA

SCHOLZ, R. W., HUTCHINSON, L. J. 1979: Distribution of glutathione peroxidase activity and selenium in the blood of dairy cows. Am. J. Vet. Res. 40: 245-249

SCHOLZ, R. W., COOK, L. S., TODHUNTER, D. A. 1981: Distribution of selenium dependent and nonselenium dependent glutathione peroxidase activity in tissues of young cattle. Am. J. Vet. Res. 42: 1724-1729

SMITH, K. L., HOGAN, J. S., CONRAD, H. R., 1988: Selenium in dairy cattle: its role in disease resistance. Vet. Med. 83: $72-78$

TASKER, J. B., BEWICK, T. D., CLARK, R. G., FRASER, A. J., 1987: Selenium response in dairy cattle. N. Z. Vet. J. 35: 139-140

THOMPSON, K. G., FRASER, A. J., HARROP, B. M., KIRK, J. A., BULliANS, J CORDES, D. O. 1981: Glutathione peroxidase activity and selenium concentration in bovine blood and liver as indicators of dietary selenium intake. N. Z. Vet. J. 29: 3-6

VULINEC, M., HAHN, V., MATEŠIĆ, DUBRAVKA, KLOBUČAR, Ž. 1985: Role of Selenium in the etiopathogenesis of spastic myopathy in foals. Vet. Arhiv 55 (suppl.), 86-88.

WILSON, P. S., JUDSON, G. J. 1976: Glutathione peroxidase activity in bovine and ovine erythrocytes in relation to blood selenium concentration. Br. Vet. J. 132: 428-434

WOLF, C. 1998: Selenium status of cows - deficiency or excess? The development of glutathione peroxidase activity in dairy cows and extensively managed mother cows in Mecklenburg-Vorpommern from 1993 to 1996. Praktische-Tierarzt 79: 755-759 